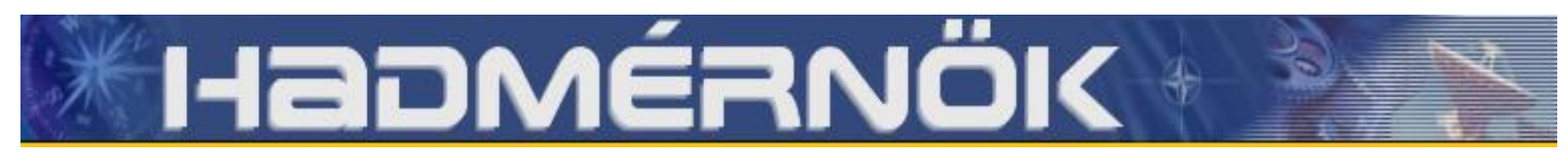

XIV. Évfolyam 1. szám - 2019. március

$10.32567 / \mathrm{hm} .2019 .1 .5$

\title{
ИСТОРИЧЕСКИЙ ОБЗОР РАЗВИТИЯ ВОЕННО-КОМАНДНЫХ ПУНКТОВ
}

\section{A KATONAI VEZETÉSI PONTOK FEJLÖDÉSÉNEK TÖRTÉNETI ÁTTEKINTÉSE}

\author{
HORVÁTH Tibor \\ (ORCID: 0000-0003-4742-847X) \\ horvathtibor@uni-nke.hu
}

\begin{abstract}
Absztrakt
При ведении боевых действий первоочередными целями были и остаются пункты управления (ПУ) различного звена и назначения. К органам управления войсками в бою и операции предъявляются высокие требования устойчивсти, непрерывности, оперативности, мобильности и др. При этом важная роль отводится фортифрикационному оборудованию районов развёртывания пунктов управления.
\end{abstract}

Kulcsszavak: пункт управления, фортифрикация, фортификационное оборудование районов

\begin{abstract}
In the conduct of hostilities, the primary targets were and remain the command points $(C P)$ of various levels and purposes. The command and control bodies in combat and operations are subject to high requirements for stability, continuity, efficiency, mobility, etc. At the same time, fortification equipment of areas where control centers are deployed plays an important role.
\end{abstract}

Keywords: control posts, fortifications, fortification equipment areas 


\section{ВВЕДЕНИЕ}

С появлением ракетно-ядерного оружия войсковые фортификационные сооружения различного назначения получили дальнейшее развитие. До этого в фортификации оснавными направлениями считались долговременная и полевая, которые сформировались ещё до начала Второй мировой войны и совершенствовались в годы войны. Послевоенный период в оснавном характеризовался анализом и обобщением полученного боевого опыта в области фортификационного оборудования рубежей, позиций и районов. Продолжились начатые в ходе войны работы по созданию новых образцов фортификационных сооружений (особенно для ведения огня), однако вскоре их начали сворачивать. [1]

Угроза применения ракетно-ядерного оружия выдвинула ряд сложных задач в развитии фортификационных сооружений. Одной из оснавных задач являлось их приведение в соответствие с новыми требованиями, особенно к защите от факторов поражения ядерного взрыва (ударная волна, световое излучение, проникающая радиация, электромагнитное излучение и радиоактивное заражение местности), а также к времени полевого фортификационного оборудования позиций и районов, которое резко сократилось. В связи с этим можно выделить три оснавных направления развития фортификации:

1. Специальные фортификационные сооружения - СФС;

2. Долговременные фортификационные сооружения - ДФС;

3. Полевые (войсковые) фортификационные сооружения - ПФС (ВФС).

Главным назначением специальных фортификационных сооружений являлось обеспечение решения стратегических задач в интересах обороноспособности страны, а их создание и применение осуществляось в соответствии с концепциями подготовки военной инфраструктуры страны.

Долговременные фортификационные сооружения как были, так и остались служить для инженерного заблаговременного оборудования рубежей позийий и районов. Их возведение и использование осуществлялось при подготовке театров военных действий в мирное время и в угрожаемые периоды в соответствии с планами оборонительногостроительства военных округов при решении стратегических и оперативно-тактических оборонительных задач. Долговременные фортификационные сооружения возводились, как правило, из долговечных и прочных материалов (железобетона, металла и др.), оборудовались системами энерго-, воздухо-, водоснабжения и канализации, обеспечивающими их длительное боевое использование.

Полевые (войсковые) фортификационные сооружения служили для инженерного оборудования позиций и районов расположения войск и должны были возводиться по всей глубине одновременно, обеспечивая постоянную готовность войск к выполнению боевых задач и непрерывное наращивание степени их защиты от средств поражения. Полевые (войсковые) фортификационные сооружения строились силами войск и в военное время, как правило, с использованием местных материалов, а также элементов промышленного изготовления. [2]

Настоящее время полевые фортификационные сооружения, в оснавном, вышёл из обихода и заменён на войсковые фортификационные сооружения. Это обусловлено схожестью конструктивных решений ВФС (сборные, сборно-разборные,блочные итд. Завадского изготовления) и сценариями их применения (могут возводиться и при заблаговременном инженерном оборудовании позиций, районов по планам командования). 
По моему, и я в этом убеждён, что конструкции долговременных фортификационных сооружений в современных условиях приближаются к конструкциям специальных фортификационных сооружений, так как их онавные отличительные признаки (время возведения, применяемые материалы и сопутствующие технологические процессы) аналогичны. Кроме того, появление высокоточного оружия в обычном снаряжении требует специальных защитных конструкций и устройств. В настоящее время номенклатура ВФС включает все сооружения открытого и закрытого типов по назначению, конструктивным решениям и применяемым материалам завадского изготовления. Сегодня отсутствуют конструкции ВФС из монолитного и сборномонолитного железобетона и специальные установки вооружения. [10]

\section{ФОРТИФИКАЦИОННОЕ ОБОРУДОВАНИЕ ПУНКТОВ УПРАВЛЕНИЯ}

Пункты управления - спеиально оборудованные и оснащённые техническими средствами места, с которых командующий (командир) с офийерами штаба осуществляет управление войсками (силами) при подготовке и ведении боевых действий или во время боевого дежурства.

Давайте посмотрим, что же представляло собой фортификационное оборудование районов развёртивания Пунктов Управления (ПУ) до, в ходе и после войны перед появлением ракетно-ядерного оружия. В эти периоды можно говорить об ирженерном оборудовании пунктов управления для их надёжной защиты от воздействия противника. Инженерное оборудование ПУ подразумевает решение задач разведки, разминировантя, маскировки, водоснабжения и фортификационного оборудования, Характер фортификационного оборудования - это номенклатура ВФС, которая возводится на ПУ, а выполнение задач в объёме первой очереди для ПУ подразумевает возведение ВФС закрытого типа - убежищ и блиндажей. Эти термины уже начинали использовать в середине 1960-х годов, а затем закрепили их в документах. Фортификационные сооружения (ФС) подразделялись на наблюдательные и командирские наблюдательные пункты, убежища и укрытия.

Наблюдательные пункты (НП) предназначались для безперебойного наблюдения за полем боя, а командирские - ещё и обеспечивали ведение штабной работы,

Командный пункт (КП) командира стрелкового полка состоял из командирского наблюдательного пункта с дополнительными НП, убежища для командира, оперативной группы и узла связи, КП артиллерийского начальника из убежищ и укрытий для обслуживающей группы, соединённых между собой крытым ходом сообщения. Степень защиты сооружений зависела от наличия времени, сил и средств. [5]

КП командира стрелковой дивизии состоял из командирского НП, убежищ для оперативной группы и для узла связи, КП начальника артиллерии и убежищ для обслуживающей группы. При заблаговременном оборудовании КП командира стрелковой дивизии устраивали усиленного или тяжелого типов.

Устойчивость функционирования пунктов управления обеспечивалась их рассредоточенным размещением - преимущественно в районах с естественными «масками» (закритые сверху кроной деревьев, в лощинах, оврагах и др.) и прикрытых труднодоступными для твнков противника препятствиями, а также фортификационными сооружениями (землянками, щелями, убежищами и укрытиями). При этом важная роль отводилась подвижным средствам связи. Подвижные командные пункты всех инстанций размещались вблизи района боевых действий в укрытиях и перемещались, как правило, один раз в сутки.

В районах развёртивания ПУ для защиты, работы и отдыха возводились убежища легког, усиленного и тяжёлого типа. Так, например, при организации обороны под Курском в тактическом звене из более тысячи командных и наблюдательных пунктов 
60\% были оборудованы убежищами усиленного типа с мощными деревоземлянными перекрытиями. Оснавным строительным материалом полевых фортификационных сооружений в этот период оставался круглый лес. Убежища на КП возводились, как правило, по типовым проектам и планировкам. [5]

Эти конструктивные решения ПФС для ПУ применялись до появления ракетноядерного оружия. После этого начался особый период развития укреплённых районов с использованием накопленного опыта в части фортификационных сооружений для ведения огня. Однако полевая фортификация (особенно в части фортификационных сооружений для оборудования ПУ) в начале 1950-х годов ещё только приступила к созданию научного и конструктивного заделов с учётом возможностей отечественной промышленности.

В конце 1940-х и в начале 1950-х годов резко обострилось противоречие между требуемым временем на инженерное оборудование районов развёртывания ПУ и реальным временем на возведение типовых фортификационных сооружений, особенно убежищ. Оно было обусловлено сокращением отводимого времени на фортификационное оборудование позиций и районов, отсутствием в войсках соответствующих сооружений промышленного изготовления и средств механизации работ для их возведения. Эти причины дали «толчок» к разработке новых направлений по созданию «полевых оборонительных сооружений» различного назначения. В первую очередь, требовалось оценить соответствие защитных свойств существующих конструкций фортификационных сооружений требованиям к воздействию поражающих факторов ядерного оружия.

Следует отметить, что промышленность Германии, Велико-Британии, Франции, США и другых стран к началу Второй мировой войны освоила производство разнообразного сортамента волнистого железа (в основном, оцинкованного). Оно получило широкое распространение в различных областях строительства. В Германии волнистое железо во время войны было быстр приспасоблено для военных нужд. Жёсткость профиля волнистого железа, относительно малый вес элементов, прочность конструкции из этих элементов, малые габариты сооружений, быстрота и простота сборки конструкций из стандартных элементов, транспортабельность и ряд других положительных качеств обеспечили его широкое использование в полевой фортификации Германии при организации оборонительных действый. [10]

В России гофрированное железо появилось в 1875 году. После первых успешных испытаний, проведённых на Петербургском ьеталлическом заводе, были впервые предложены металлические гофрированные трубы, которые использовались для замены деревянных труб на железной дороге. Однако дальнейшего развития это перспективное направление по целому ряду причин тогда не получило. Отечественная промышленность выпускала только плоское волнистое железо и притом ограниченного сортамента. Гнутое волнистое железо,несмотря на простату изготовления, не проводилось из-за отсутствия спроса со стороны строительных организаций. К этому времени волнистое железо получило название «волнистая сталь», которое было закреплено в ГОСТ 3685-47. Оно изготавливалось путём горячей и холодной прокатки из тонколистовой стали обыкновенного качества на заводах Министерства металлургической промышленности CCCP.

\section{опыт войны}

Входе Великой Отечественной войны и в первые послевоенные годы тщательно изучалась практика полевого оборонительного строительства Германии, определялись и оценивались оснавные наиболее распрасранённые типы и конструкции фортификационных сооружений, а также материалы, из которых они возводились. 
Немецкые войска на протяжении войны использовали в фортификации бронеконструкции заводского изготовления не только для ведения огня, но и для защиты личного состава и командных пунктов, элементы и секции волнистого железа, а также готовые элементы из дерева и фанеры. Много сооружений из волнистого железа немцы возвели при оборудовании Ломжинского плацдарма, в полевой обороне при осаде Ленинграда, в системе обороны. Причём сооружения из волнистого железа строили не только в безлесных районах, но и там где лес был в изобилии.

При оборудовании ниш, скрытых ходов сообщения, блиндажей и убежищ исползовались секции волнистого железа «Зигфрид», а также прямые и изогнутые (криволинейные) элементы «Генрих». В результате изучений этих элементов и трофейных материалов пришлы к выводу, что размеры гнутого волнистого железа не могут соответствовать задачам полевой фортификации - требовалось изыскать рациональные конструктивные формы, а не копировать иностранные образцы.

К началу 1950-х годов стратегическая авиация США имела на вооружении более 700 атомных бомб. Фмериканцы провели 45 ядерных испытаний, включая бомбардировки японских городов Хиросимы и Нагасаки в 1945 году. В Советском Союзе к этому моменту провели всего восемь испытаний атомного оружия, были изучены результаты атомной бомбардировки авиацией США японских городов Хиросимы и Нагасаки. В интересах совершенствования противоатомной защиты войск, проверки расчётных нормативов по поражению атомным оружием техники и вооружения требовалось провести учение с максимальным приближением к реальной обстановке. В связыи с этим, 29-го сентября 1953 года вышло постанавление Совета Миристров СССР, положившее начало подготовке Вооруженных Сил и страны к действиям в особых условиях.

14-го сентября 1954 года состоялись Тоцкие войсковые учения с участием военнослужащих, в ходе которых применялся подрыв ядерных боеприпасов. 17-го сентября 1954 году в газетах появилось следуюшее сообшение: «В соответствии с планом научно-исследовательских и эксперементальных работ в последние дни в Советском Союзе было проведено испытание одного из видов атомного оружия. Целью испытания было изучение действия атомного взрыва. При испытании получены ценные результаты, которые помогут советским учёным и инженерам успешно решить задачи по защите от атомного нападения». [9]

На полигоне выполнили полное фортификационное оборудование позиций и районов, возвели сооружения открытого типа и закрытог типа (огневые, блиндажи и убежища из лесоматериала, с применением волнистой стали и из сборного железобетона), установили контрольно-измерительные средства.

Результаты учений были проанализированы и обобщены. На основании результатов натурных испытаний, научных и экспериментальных исследований были разработаны теоретические основы расчёта конструкций ФС на действие поражающих факторов ядерного взрыва и выданы практические рекомендации по проектированию новых и приведению существующих сооружений в соответствие с новыми требованиями. В ходе исследований были выявлены самые слабые места фортификационных сооружений входы, амбразуры, воздухозаборные, дымовые отверстия и места ввода коммуникаций (электричество, связь и другие), которые следовало оборудовать защитными устройствами (защитными дверями, защитными клапанами итд.). Наиболее рациональными конструктивными решениями по несущей способности и материалоёмкости при воздействии ударной волны ядерного взрыва были определены круговая и арочная формы поперечного сечения остова сооружения для промышленной разработки. Вплоть до середины 1980-х годов именно они определяли технический 
облик войсковых фортификационных сооружений промышленного изготовления для ПУ. [9]

К середине 1950-х годов при инженерном оборудовании ПУ предпысивалось возводить типовые фортификационные сооружения из лесоматериала, с использованием элементов волнистой стали и сборного железобетона, которые были приведены в соответствие с новыми требованиями, Одноко время возведения оставалось на прежнем уровне, что не удовлетворяло требованиям ведения манёвренных боевых действий, особенно при оборудовании пунктов управления. Вопросы размещения и защиты подвижных средств связи в специально устраиваемых укрытиях в районах развёртывания ПУ в наставлениях и руководствах в 1956 году не были отражены. Это, вероятнее всего, было связано с незаконченностью исследований на ударных трубах по оценке защитных свойств укрытий и окопов для техники при воздействии скоростного напора и воздушной ударной волны ядерного взрыва.

Быстротечность обстановки, ограничееые сроки для оборудования, частая смена районов развёртывания ПУ обусловили необходимость перехода к принципиально новым техническим формам конструкций фортификационных сооружений. Были сформулированы оснавные направления их развития:

1. приведение в соответствие существующих типовых сооружений к новым требованиям по защитным свойствам;

2. разработка сборно-разборных полевых сооружений из новых материалов;

3. разработка подвижных полевых сооружений.

В качестве основой концепции при их разработке было принято создание фортификационных сооружений промышленного изготовления - полной заводской готовности к применению. [11]

В это же время впервые провели ряд НИР по унификации и стандартизации наиболее массовых типов полевых фортификационных сооружений и их элементов, поразработке простых конструкций унифицированных сооружений, доступных для изготовления всеми родами войск, а также по использованию сборных конструкций фортификационных сооружений промышленного изготовления из волнистой стали, фанеры и сборного железобетона.

Это было вызвано тем,что к 1954 - 1955 годах в качестве типовых сооружений рекомендовались 12 видов блиндажей 6 видов убежищ лёгкого типа. Отдельные сооружения имели от 14 до 18 различных элементов, что значительно затрудняло централизованную заготовку материалов, а также сборку. Так, при оборудовании только одного батальонного района обороны на передовой позиции силами войск необходимо было возвести: подбрустверных блиндажей на 4 и 8 человек - 70-75 штук, убежищ лёгкого типа на 10-25 человек - 12-19 штук, с общей затратой лесоматериалов на блиндажи и убежища до 500-600 м3.

Проводились НИР по созданию фортификационных сооружений из стандартных элементов волнистой стали отечественного производства. В результате исследований и испытаний трофейных образцов волнистого железа и опытных отечественных образцов волнистой стали были установлены: рацональный профиль, толщина листа волнистой стали, размеры и типы конструкий стандартного элемента из фортификационной волнистой стали для возведения сооружений на позициях, в районах ПУ.

Определили номенклатуру сборных полевых сооружений из стандартных элементов волнистой стали. К ним относились: убежища различного назначения, помещенияубежища для отделов штаба полка, дивизии, корпуса на НП, подземная часть сооружений НП, помещения-убежища для командиров батальонов, полков, начальников родов войск, различные блиндажи, укрытия, заслоны, а также обделка ниш, галере итд. 
Уточнили и тактико-технические требования к полевым фортификационным сооружениям, которые могут быть выполнены из стандартных элементов волнистой стали. Разработали технические проекты фортификационных сооружений установленного типа, а также заказали опытные партии стандартных элементов из волнистой стали на отечественной промышленной базе.

\section{ПЕРВЫЕ СЕРИЙНЫЕ СООРУЖЕНИЯ}

С учётом полученных результатов в Отдельном проектно-фортификационном бюро Инженерных войск Советской армии совместно с НИИИ имени Д. М. Карбышева спроектировали сооружения промышленного изготовления из волнистой стали и водостойкой фанеры для инженерного оборудования ПУ. Уже в 1956-1957 годах на Днетропетровском заводе металлоконструкций выпустили опытные образцы комплекта элементов волнистой стали КВС и сооружение КВС-У, а на Парфинском фанерном комбинате - сооружение из бакализорованной фанеры КФУ. [6]

КВС-У и КФУ стали первыми образцами конструкций сборно-разборных сооружений промышленного изготовления многократного использования при инженерном оборудовании ПУ. Они отличились по форме и конструктивному исполнению.

Комплект елементов волнистой стали КВС был разработан для возведения блиндажей и убежищ, перекрытых щелей, участков таншей с минимальным использованием лесоматериалови в сочетании с бумажными земленосными мешками - при инженерном оборудовании позиций и районов.

КВС-У - сооружение полной заводской готовности, предназначенное для инженерного оборудования ПУ в ходе подготовки исходных районов для наступления, при наступлении и закреплении захваченных рубежей, а также в обороне - при оборудовании позиций войск на главном направлении в первой полосе обороны тактического звена, где условия не позволяли или затрудняли возводить сооружения другого типа (железобетонные, крупноблочные, итд.).

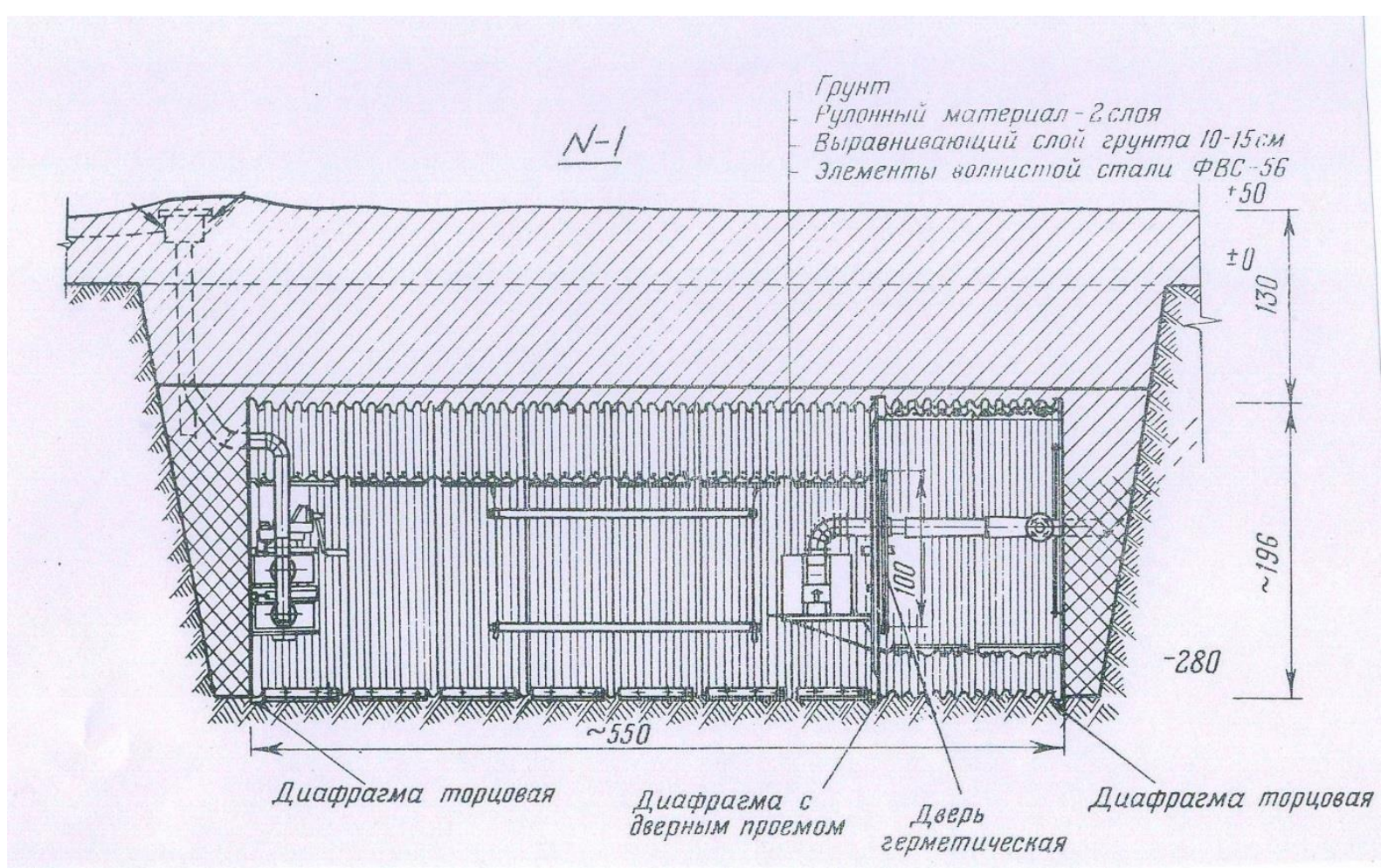

1. рис. Конструкция Волнистой Стали - Убежище (КВС - У) [12] 
КВС-У состояло из основного помещения, тамбура с шахтным входом (тамбура и входа). Остов основного помещения кольцевого очертания собирался из элементов волнистой стали ФВС (по три элемента в кольце - всего семь колец), а по длине сооружения эти элементы укладывались в нахлестку на одну полуволну.

В комплект элементов сооружения также входили специальные элементы ФВС с отверстиями для установки и крепления перископа ППК-1 или коробов (труб) для ввода кабельных линий, которые были разработаны позднее и введены в комплект КВС-У в 1959 году. Торец основного помещения закрывался специальной диафрагмой.

Тамбур собирался из четырёх элементов ФВС и покрытия тамбура, На покрытии тамбура монтировался промежуточный конус или дополнительный элемент и защитногерметический люк. Один торец примикал к основному помещению и отделялся от него перегородкой с герметической дверью, а другой торец закрывался торцовой перегородкой. Вход в тамбур оборудовался лестницей.

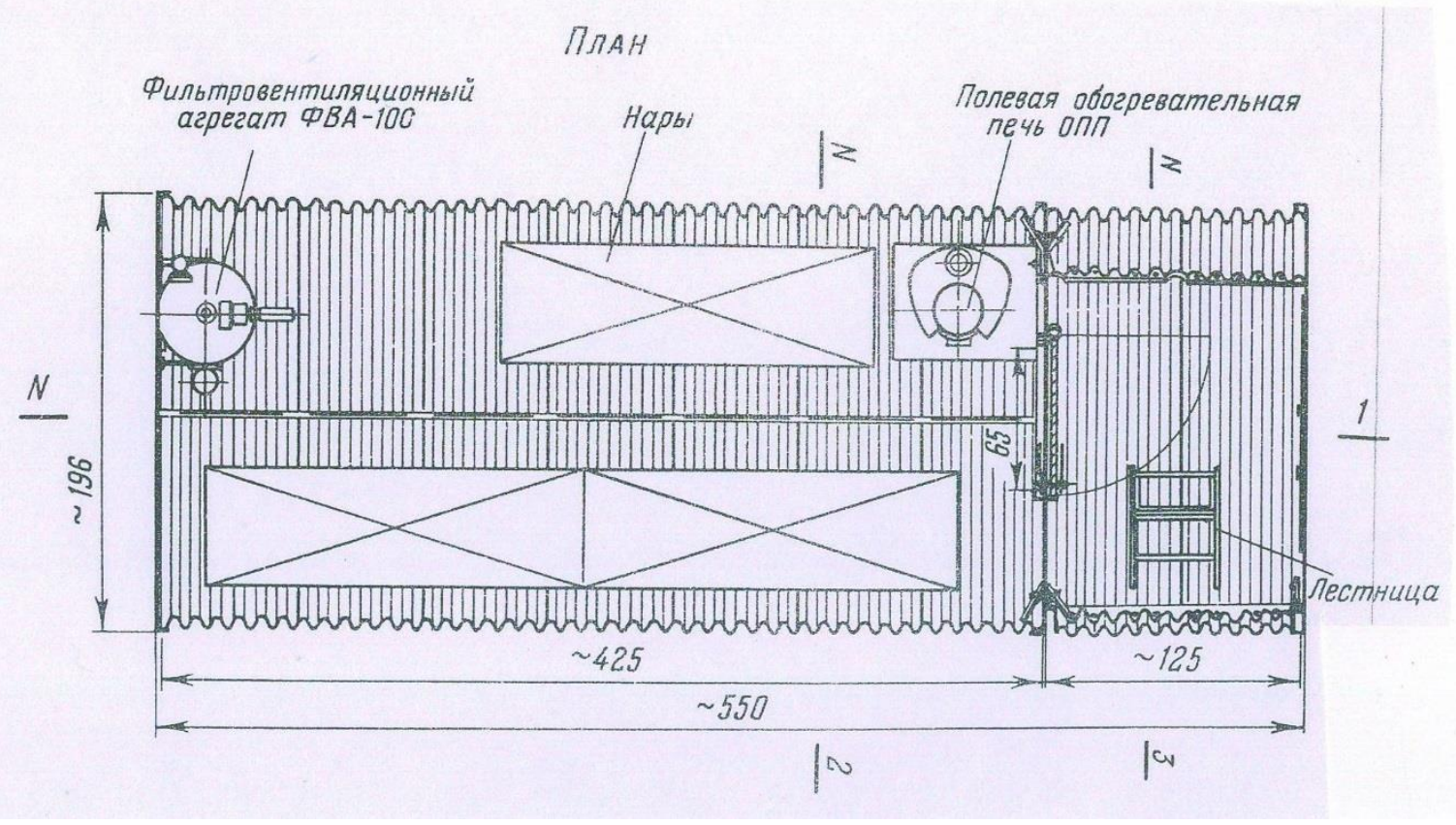

2. pис. Конструкция Волнистой Стали - Убежище (КВС - У) [12]

В основном помещении устанавливались: фильтровентиляционный агрегат ФВА-100 и печь ОПП, столы для работы и аппаратуры,нары для отдыха, табуреты и пр.

Воздухозабор ФВА-100 оборудовался вентиляционным защитным устройством ВЗУ 100, дымоход ОПП - защитным устройством ДЗУ-100.

Особой популярностью в Инженерных войсках ползовались комплекты элементов ФВС и сооружение КВС-У, разработанное для ПУ полка. [12]

Комплект КВС-У позволял увеличивать площадь основного помещения путём стыковки сооружений как в продольном направлении, так и в поперечном.

Сооружение, возведенное в грунте, обладало достаточными защитными свойствами от воздействия поражающих факторов ядерного взрыва и средств поражения боеприпасов в обычном снаряжении. Однако опыт применения и эксплуатации КВС-У выявил, что его круглая форма не позволяла рационально использовать пространство основного помещения и вызвала определённые неудобства при работе с картами и пр. Размещение ФВА и ОПП в основном помещении также не способствовало эфективной работе офицеров управления. Шахтный вход был недостаточно удобным, особенно при быстрой эвакуации из сооружения. 


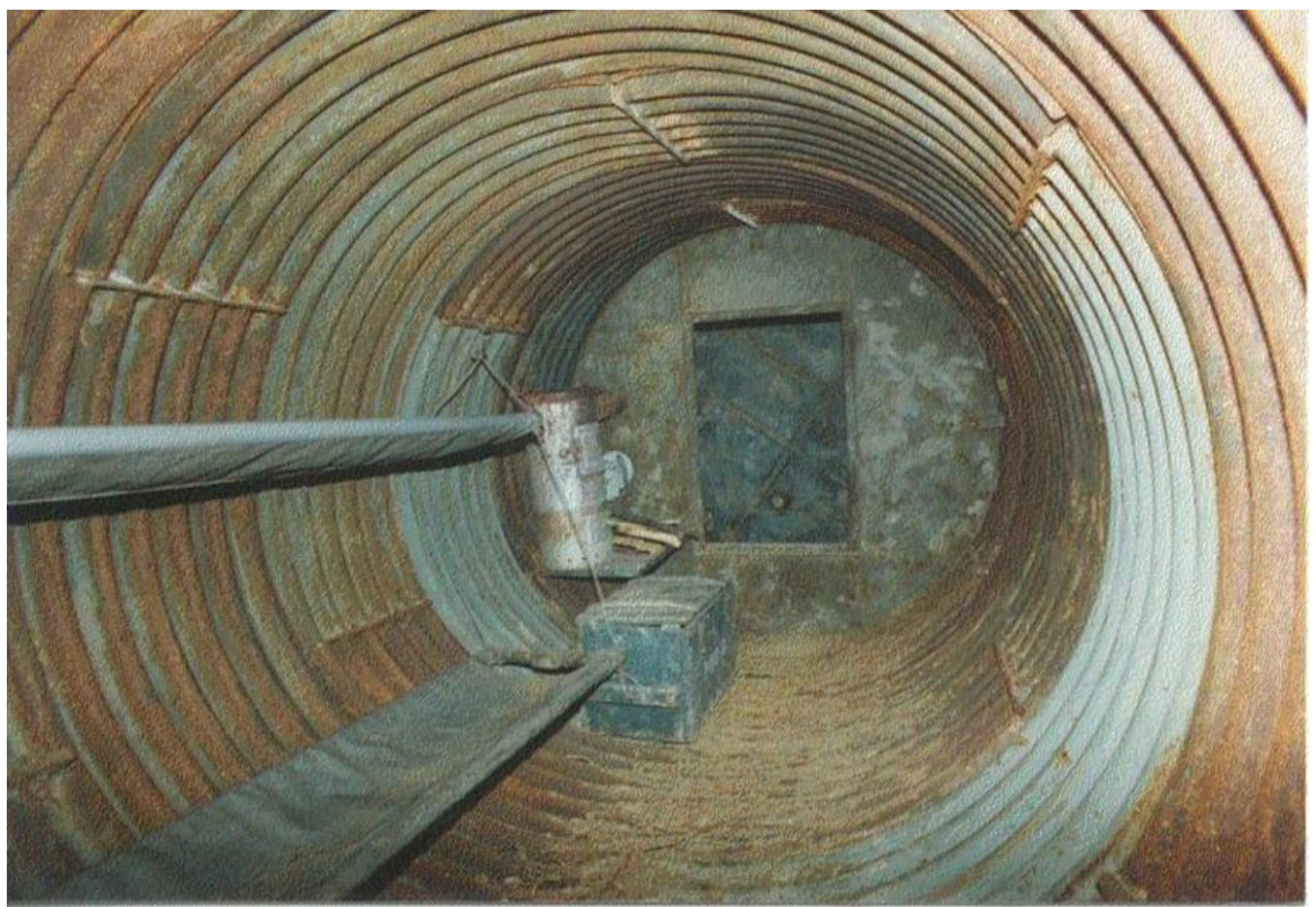

1. фото Основное помещение - Убежище (КВС - У) [7]

При сборке колец, особенно при стягивании их внахлест, расчёты должны были иметь соответствующие практические навыки работы стяжными ключами, Монтаж внутренного и бытового оборудования тоже требовал определённой сноровки и умения. При извлечении КВС-У для повторного использования требовалось польностю снимать грунтовую обсыпку и убрать грунт из пазух котлвана не менее чем на половину высаты сооружения или же отрывать по пазухе полупериметра сооружения с последующей его разборкой. Командиры подразделений, за которыми были закреплены КВС-У, для сокращения времени возведения или исключения параллельной сборки сооружения расчётом с отрывкой котлована землеройным средством и извлечения применяли его в собранном виде на подъёмной раме. Сооружение заблаговременно собиралось на поверхности земли на раме, выполненной из брёвен, и имело строповочные верёвки для установки в котлован автокраном. КВС-У перевозилось в собранном виде на раме в кузове автомобиля. При таком способе время на возведение сооружения в котловане сокращалось, однако увеличивалось количество маш-рейсов, так как штатная перевозка сооружения предусматривала перевозку двух комплектов.

Для переброски по воздуху была разработана специальная укладка элементов комплекта КВС-У. [12]

Несмотря на недостатки, сооружение КВС-У находилось в производстве более 30 лет.

Сооружение КФУ предназначалось для защиты и работы личного состава при инженерном оборудовании районов развёртывания пунктов управления оперативнотактического зиена. Это сооружение было разработано и принято на снабжение в сентябре 1958 года. 

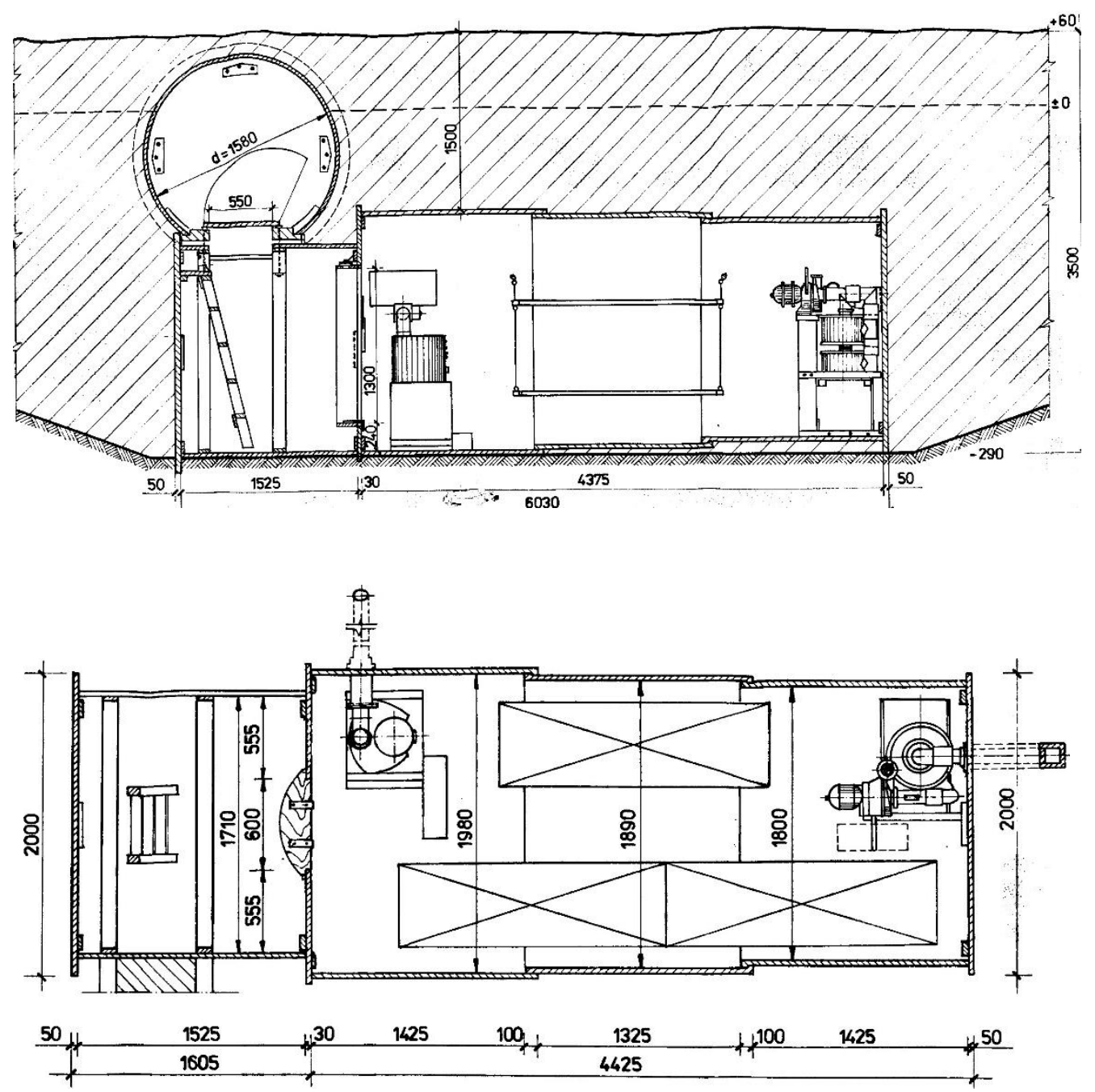

3. рис. Клейо-Фанерное Убежище (КФУ) [6]

Оно состаяло из основного помещения, тамбура и вертикального входа. Остов сооружения собирался из клееных фанерных полых цилиндричесих и плоских элементов. Как и при использовании КВС-У, увеличение площади оснавного помещения ПУ достигалось путём стыковки комплектов сооружений КФУ между собой. [6]

В оснавном помещении устанавливали фильтровентиляционный агрегат ФВА-50/25 ипечь ОПП, столы для работы и аппаратуры, нары для отдыха, табуреты и пр. Вооздухозабор ФВА оборудовался вентиляционным защитным устройством ВЗУ-50, дымоход ОПП - защитным устройством ДЗУ-100. В комплект КФУ внутреннее и бытовое оборудование не входило, а поставлялось отдельно.

Цилиндрические полые элементы имели различные диаметры и при транспортировке их вдвигали один в другой (телескопический принцип), образуя компактный блок. Штатно на грузовой платформе автомобиля ЗИЛ-150 переводились два комплекта КФУ. [6]

Одновременно с разработкой комплектов сооружений КВС-У и КФУ продолжался поиск новых материалов и конструктивных решений ФВС. [12]

\section{ЗАКЛЮЧЕНИЕ}

Таким образом, уже к концу 1950-х годов в результате проведения целого ряда НИР появились новые сооружения промышленного изготовления для ПУ, а также были предложены типовые решения сооружений с использованием фортификационной 
волнистой стали и лесоматериала при инженерном оборудовании позиций и районов в условиях применения ядерного оружия. Кроме того, провели стандартизацию и унификацию элементов (из лесоматериала и железобетона) типовых конструктивных решений входов, перекрытых щелей, блиндажей и убежищ для фортификационного оборудования позиций и районов.

\section{ЛИТЕРАТУРА}

[1] Е. С. КОЛИБЕРНОВ, В. И. КОРНЕВ, А. А. СОСКОВ: Инженерное обеспечение боя. Военздат, 1984.

[2] HORVÁTH T: A személyi állomány védelmét biztosító erődítési építmények fejlődésének vizsgálata és a továbbfejlesztés lehetséges irányai. Doktori $\mathrm{PhD}$ értekezés; ZMNE, Budapest, 2003. 137 p.

[3] HORVÁTH T: A védőképesség növelésének lehetőségei az erődítés-álcázás területén Budapest: Zrínyi Miklós Nemzetvédelmi Egyetem, 2000. 126 p.

[4] HORVÁTH T: A KFU óvóhely Müszaki Katonai Közlöny 7:(3) pp. 49-52. (1997)

[5] HORVÁTH T, WANCZEL G: Csapaterődítés Szentendre: Kossuth Lajos Katonai Föiskola, 1995. $44 \mathrm{p}$.

[6] Б. В. ВАРЕНЫШЕВ, К. Н. ДУБИНИН, И. П. МУДРАГЕЙ: Военно-инженерная подготовка. Военздат, 1982.

[7] HORVÁTH T: A Magyar Honvédségben korábban rendszeresített, a személyi állomány védelmét biztosító építmények. Müszaki Katonai Közlöny XXVIII: 4 pp. 174-192. 2018.

[8] Sz. A. ANANICS-P. K. BUZNYIK-A. I. SZUHAREV: Fortifikácia. Voennoe Izdatyelsztvo. 13/89735p. Moszkva, 1984.

[9] HORVÁTH T: Войсковые фортификационные сооружения для пунктов управления. Hadmérnök XIII : 3 pp. 114-123. 2018.

\section{A KATONAI VEZETÉSI PONTOK FEJLŐDÉSÉNEK TÖRTÉNETI ÁTTEKINTÉSE}

\section{Absztrakt}

A katonai müveletek vezetése és végrehajtása során az elsődleges célpontok mindenkor a különböző vezetési szintek és azok létesítményei voltak és maradnak is. A harcokban és a müveletekben müködő parancsnoki- és vezető szervek magas követelményeket támasztanak a stabilitás, a folytonosság, a hatékonyság, a mobilitás stb. tekintetében. Ugyanakkor továbbra is fontos szerepet játszanak a vezetési pontokon kiépítésre kerülö, különböző rendeltetésű csapaterődítési építmények. Ezen csapaterődítési építmények közé tartozik a cikkben bemutatott két építmény is.

Kulcsszavak: vezetési pont, eröditési épitmény, óvóhely 